\title{
RELEVANSI TERMINOLOGI STRUKTUR MASYARAKAT ACEH TERHADAP WARNA KEBANGSAAN INDONESIA
}

\author{
(TERMINOLOGICAL RELEVANCE OF ACEHNESE \\ STRUCTURE TO THE COLOR OF INDONESIAN NATIONALITY)
}

\author{
Teguh Santoso, S.S., M.Hum. \\ Balai Bahasa Banda Aceh \\ Jalan Panglima Nyak Makam 21, Banda Aceh \\ Posel: teguhsantoso@kemdikbud.go.id
}

\begin{abstract}
Terminology is one of Linguistics fields. With regard to this, there are many linguistic data related to the terminology. One of Indonesian terminologies in terms of social structure can be found in Aceh province. The Acehnese structure is divided into the highest level to the lowest level. These structural levels are known as mukim, gampong, sagoe, etc. The terminology can be optimized in terms of contributing to the color of Indonesian nationality. Accordingly, the unity in diversity is not abondoning the roots of local culture.

Key words: terminology, Aceh, nationality
\end{abstract}

\begin{abstract}
Abstrak
Terminologi merupakan salah satu bidang di dalam linguistik. Berkaitan dengan hal tersebut, banyak sekali data kebahasaan yang berkaitan dengan terminologi tersebut. Salah satu terminologi di Indonesia yang berkaitan dengan struktur sosial dapat dijumpai di Provinsi Aceh. Struktur masyarakat Aceh terbagi dari tingkatan paling tinggi hingga tingkatan paling rendah. Tingkatan struktural ini dikenal dengan istilah mukim, gampong, sagoe dan sebagainya. Terminologi tersebut dapat dioptimalkan dalam kaitannya dengan sumbangsih terhadap warna kebangsaan Indonesia. Dengan demikian, kesatuan dalam keanekaragaman tidak meninggalkan akar budaya setempat.
\end{abstract}

Kata kunci: terminologi, Aceh, kebangsaan

\section{Pendahuluan}

Indonesia beberapa kurun waktu terakhir ini mengalami krisis. Krisis yang terus melanda, salah satunya, adalah krisis identitas. Hal ini dapat diketahui dari banyaknya kejadian yang membuat bangsa ini tidak lagi percaya pada kekuatan diri sendiri dalam membangun atau mengatasi segala macam persoalan. Penyelesaian atas satu masalah lebih ber- sifat pada kepentingan golongan daripada kepentingan bangsa. Fenomena ini telah merambah ke berbagai sektor kehidupan. Pada lingkup Provinsi Aceh juga demikian. Aceh selalu penuh dengan kontroversi yang terkadang tidak diselesaikan dengan memanfaatkan kekayaan budaya dalam penanganannya. Hal ini yang terkadang membuat penyelesaian sebuah perkara menjadi berlarutlarut. 
Nasionalisme bangsa ini sedang diuji dan akan terus diuji. Hal ini ditambah dengan globalisasi yang membuka hampir setiap ruang dalam kehidupan berbangsa dan bernegara kita. Oleh karena itu, sudah saatnya bangsa ini kembali pada niat awal pendiri bangsa dengan konsep Bhinneka Tunggal Ika-nya. Keberagaman yang dimiliki oleh bangsa Indonesia menjadi modal yang sangat kuat bagi pengembangan kekuatan jati diri dan pembangunan karakter bangsa.

Salah satu hal apabila kita berbicara tentang karakter bangsa adalah bahasa. Indonesia memiliki ratusan bahasa daerah. Kekayaan nonbenda berupa bahasa ini membuat peran bahasa persatuan sangatlah penting. Sedemikian pentingnya peran bahasa akan menjadi tolok ukur bagi bangsa Indonesia dalam menentukan masa depannya. Secara khusus, domain bahasa daerah yang ada di dalam wilayah negara Indonesia menjadi sesuatu yang sangat besar andilnya dalam memberikan warna terhadap bangsa dan negara Indonesia.

\section{Lingkup Terminologi}

Kamus Besar Bahasa Indonesia (KBBI) edisi ke3 menyebutkan pengertian terminologi pada dua hal; peristilahan (tentang kata-kata) dan ilmu mengenai batasan atau definisi istilah (2005:1.184). Terminologi pada artikel ini lebih condong pada pengertian terminologi yang menyangkut pada aspek peristilahan. Terminologi yang ada pada struktur masyarakat Aceh mengacu pada satu definisi tertentu. Terminologi inilah yang selanjutnya akan dibahas dalam kaitannya dengan kebhinnekaan bangsa Indonesia pada sisi budaya.

Terminologi pada satu sisi dapat dikaji untuk mengetahui sejarah atau asal-usul terjadinya sebuah istilah. Pada tingkatan yang lebih tinggi, terminologi dapat pula menjadi salah satu pengisi spirit berupa kekuatan heroik yang ditimbulkan oleh terminologi tersebut. Satu contoh misalnya di dalam komunitas Aceh, ketika masa konflik masih melanda daerah ini, terminologi panglima sagoe mampu memberikan semangat dalam memberikan "perlawanan". Hal ini terjadi juga pada terminologi lain yang mampu memberikan sumbangan kekuatan atau menjadi kekuatan moral dalam berjuang. Saat ini, hanya bagaimana masyarakat dan pemerintah mengelola ini semua. Terminologi yang ada dianggap sebagai kekayaan. Kekayaan dalam memberikan dukungan moral terhadap pembangunan, baik fisik maupun nonfisik yang sedang berjalan saat ini. Sudah saatnya terminologi yang bernuansa daerah tidak diberangus dan disamaratakan. Masing-masing harus tetap eksis sebagai wujud komunal sebuah masyarakat, seperti halnya yang terjadi dan berjalan di Aceh.

\section{Struktur Masyarakat Aceh}

Sebagaimana diketahui bahwa Aceh merupakan wilayah yang dulu dikenal sebagai kerajaan dan wilayahnya termasyhur dengan sebutan Nanggroe Aceh dengan wilayah kekuasaan meliputi hampir seluruh Pulau Sumatera hingga Semenanjung Malaka. Kerajaan Aceh dahulu terkenal dengan armada lautnya dan pasukan militernya, sehingga negara-negara asing mengaguminya. Puncak kejayaannya pada masa Sultan Iskandar Muda yang memegang tampuk Kerajaan Aceh tahun 1607 s.d. 1638.

Kerajaan Aceh pada masa jayanya memiliki peran yang sangat penting dan berpengaruh besar dalam percaturan politik dunia, terutama di bidang perdagangan. Kemasyhuran Kerajaan Aceh selain mempunyai peradaban yang tinggi juga mempunyai struktur pemerintahan serta keteraturan sistem pemerintahan sehingga masyarakat dapat mengembangkan dirinya sebagaimana masyarakat lainnya di dunia ini. Struktur pemerintahan Aceh atau struktur 
masyarakat Aceh dapat membentuk suatu sistem masyarakat yang stabil dan menjadi lembaga yang dapat menjaga atau sebagai pengendali sosial dalam masyarakat.

Seperti disebutkan dalam Kanun Meukuta Alam Al-Asyi (Usman, 2003:44), Kerajaan Aceh tersusun sebagai berikut: gampong (kampung), mukim (federasi kampung-kampung), nanggroe (kecamatan), dan sagoe (federasi dari nanggroe-nanggroe). Untuk lebih jelasnya dapat dilihat pada uraian berikut ini.

1. Gampong, istilah ini sering juga disebut dengan meunasah, dipimpin oleh seorang keusyik (kepala desa) dan seorang imam rawatib dengan dibantu oleh sebuah staf yang diberi nama tuha peut. Pemerintahan gampong ini mendapatkan otonomi yang luas.

2. Mukim, yaitu federasi dari beberapa gampong, paling kurang terdiri atas delapan gampong. Mukim dipimpin oleh seorang Imuem Mukim dan seorang kadhi mukim serta dibantu oleh beberapa orang waki. Dalam setiap mukim didirikan sebuah masjid Jumat.

3. Nanggroe, atau disebut juga uleebalang terdiri atas 3 mukim, 4 mukim, $5 \mathrm{mu}$ kim, 7 mukim, 8 mukim, atau 9 mukim. Nanggroe dipimpin oleh seorang Uleebalang dan dibantu oleh seorang kadhi nanggroe. Nanggroe merupakan daerah otonomi dengan batas-batas tertentu.

4. Sagoe yaitu federasi dari beberapa nanggroe. Sagoe ini terdiri atas tiga jenis yaitu:

a. Sagoe Teungoh Lheeploh, terdiri atas 25 mukim, yang dipimpin oleh seorang panglima sagoe yang bergelar kadhi Malikul Alam Sri Setia Ulama, dan dibantu oleh seorang kadhi sagoe yang bergelar Kadhi Rabbul Jalil.

b. Sagoe Duaplooh Nam, terdiri atas 26 mukim, yang dipimpin oleh se- orang panglima sagoe, yang bergelar Sri Imam Muda dan dibantu oleh seorang kadhi sagoe yang bergelar Kadhi Rabbul Jalil.

c. Sagoe Duaplooh dua, terdiri atas 22 mukim yang dipimpin oleh seorang panglima polem sri muda perkasa dan dibantu oleh seorang kadhi yang bergelar kadhi rabbul jalil.

Secara lebih detail, struktur Kerajaan Aceh Darussalam merupakan suatu struktur masyarakat yang sangat sempurna menurut ukuran waktu itu. Struktur kerajaan atau sistem lembaga masyarakat Aceh dapat memenuhi kebutuhan untuk mengendalikan perilaku masyarakat. Kehadiran lembaga tersebut sebagai pengontrol dan pengendali terhadap sosial keagamaan yang ada dalam masyarat Aceh.

Gampong dalam masyarakat Aceh, merupakan suatu sistem kemasyarakatan yang dapat mengatur diri sendiri sekaligus gampong sebagai suatu kesatuan yang mengorganisasikan masyarakat yang berdomisili di lingkungan administrasi atau lingkungan hukum desa. Struktur kepemimpinan Gampong sampai saat ini masih berlaku atau berfungsi sebagaimana sediakala.

Di samping itu, antara atau beberapa gampong-gampong dipimpin oleh seorang Mukim. Hasil dari federasi atau kesatuan gampong--gampong tersebut maka yang membawahi kesatuan gampong--gampong tersebut dikepalai oleh seorang Mukim atau imeum Mukim. Seorang Imeum Mukim dibantu oleh Kadhi Mukim dan dibantu oleh beberapa orang staf. Imeum Mukim pada Kerajaan Aceh Darussalam atau sebelum kemerdekaan sangat berpengaruh dan berwibawa. Akan tetapi setelah Indonesia merdeka pengaruh Mukim cenderung menurun, karena tidak diberi wewenang mengatur wilayahnya lagi. Hurgronje, menyebutkan: Para Imeum itu sesungguhnya adalah pembe- 
sar adat tanpa sifat keagamaan. Ada di antaranya yang telah mencapai kedudukan mandiri sederajat dengan Uleebalang. Dalam struktur masyarakat Aceh Mukim merupakan suatu pemimpin yang dapat menjaga dan mengayomi masyarakat, terutama tempat berkonsultasi serta tempat bertanya bagai masyarakat setempat.

Di samping itu pada pemerintahan Kerajaan Aceh, Mukim merupakan bawahan atau di bawah kedudukan Uleebalang. Dengan kata lain Kepala Mukim diangkat dan diberhentikan oleh Uleebalang. Dalam wilayah kekluasaan Mukim yang merupakan kesatuan dari gampong, didirikan sebuah Mesjid Kemukiman. Mesjid Kemukiman dapat menampung ribuan jamaah. Karena di Aceh umumnya dulu pengikut Imam Syafi' i, maka sembahyang Jumat dianggap sah setelah mencapai paling sedikitnya 40 orang. Wewenang kepala Mukim dulu sangat besar namun kini sudah menurun peranannya, walaupun demikian Kepala $M u$ kim sampai sekarang masih berpengaruh terutama dalam pengangkatan camat-camat di kecamatan. Kebijakan camat saat ini apabila tidak disetujui oleh Kepala Mukim, tidak dapat dijalankan.

Sedangkan Nanggroe yang disebut juga daerah Uleebalang terdiri dari tiga Mukim atau lebih. Uleebalang dibantu oleh seorang Kadhi Nanggroe. Dalam hal ini Nanggroe merupakan daerah otonom dalam hal tertentu. Uleebalang adalah kepala wilayah tertentu. Seorang Uleebalang berkedudukan sangat tinggi pada zaman kerajaan. Para Uleebalang atau kepala wilayah kadang-kadang disebut dengan Raja diangkat oleh Sultan Aceh. Oleh karena itu, para Uleebalang mempunyai hak otonom mengurusi daerah-daerah dalam hal tertentu, asal tidak bertentangan dengan Kanun Al-Asyi atau Undang-undang Nanggroe Aceh Darussalam. Dalam hal ini di wilayah kekuasaan Uleebalang tidak terdapat nama khas seperti nama Mukim, atau Gampong, akan tetapi disebut dengan Nanggroe.

Nanggroe, merupakan suatu wilayah yang dipimpin oleh seorang Uleebalang. Nanggroe mempunyai wilayah secara struktur dan hukum. Artinya Nanggroe merupakan wilayah-wilayah yang dikomandoi oleh Uleebalang. Namun demikian, kebijakan-kebijakan yang dicanangkan atau diputuskan oleh Uleebalang tidak boleh bertentangan dengan hukum yang berlaku di Kerajaan Aceh. Di samping itu, Nanggroe merupakan wilayah perluasan dari Uleebalang yang telah ditentukan oleh Kerajaan Aceh. Pada suatu wilayah, misalnya sebelumnya tidak mempunyai penduduk, tetapi setelah berkonsultasi dengan kerajaan maka para penduduk beserta seorang Uleebalang membuka suatu pemukiman baru, maka seorang Uleebalang tersebut dapat memerintah dengan keputusan Kerajaan Aceh.

Uleebalang merupakan pembantu sultan dalam mengurus kebijakan atau ketentuanketentuan yang telah diputuskan oleh sultan bersama hakim. Sedangkan kebijakan Uleebalang tidak dapat dibantah oleh Uleebalang yang lainnya kecuali sultan. Menurut Hurgronje para Uleebalang selain dibantu oleh Kadhi dan Imeum juga dibantu oleh Banta. Para pembantu atau disebut dengan banta biasanya adik kandung dari Uleebalang, ataupun kerabat yang dapat dipercaya. Di samping para pembantu ada yang disebut dengan Kawom rakan, yaitu pembantu Uleebalang, biasanya berdekatan dengan rumah Uleebalang. Dan para pembantu lain disebut dengan panglima perang yang dipercaya oleh Uleebalang.

Sedangkan Sagoe yaitu federasi dari beberapa Nanggroe. Wilayah Sagoe yang dipimpin oleh panglima Sagoe hanya ada di Aceh BesarPanglima Sagoe dibantu oleh Kadhi Rabul Jalil. Wewenang panglima Sagoe hanya terbatas pada kepentingan bersama antara beberapa orang Uleebalang. Peranan 
panglima sagoe tidaklah otonom dibandingkan dengan Uleebalang, akan tetapi kebijakan dari Panglima Sagoe untuk kepentingan bersama dalam beberapa Mukim dan wilayah Uleebalang. Sagoe merupakan suatu wilayah yang terdiri dari beberapa Nanggroe yang di dalamnya terdapat beberapa Uleebalang. Sagoel adalah wilayah yang tidak otonom dibandingkan dengan Nanggroe. Demikian juga Sagoe juga tidak terdapat di seluruh Aceh. Namun demikian, Sagoe yang dipimpin oleh Panglima Sagoe mempunyai peranan dalam memberikan masukan terhadap para Uleebalang yang memerintah di beberapa Nanggroe di wilayah Panglima Sagoe.

Terakhir adalah kerajaan, yaitu sistem kenegaran yang mempunyai wilayah undang-undang serta batas-batas wilayah. Kekuasaan Kerajaan Aceh mulai di ujung barat Pulau Sumatra sampai ke Bengkulu dan Semenanjung Malaka. Kerajaan Aceh dipimpin oleh seorang raja yang bergelar Sultan Imam Malikul Adil, dan dibantu oleh seorang Kadhi kerajaan yang bergelar Kadhi Malikul Adil. Kerajaan Aceh merupakan kerajaan yang berpengaruh di kawasan Asia Tenggara, terutama pada abad ke-14 sampai abad ke-18. Kerajaan Aceh adalah suatu kerajaan yang berdasarkan Undang-Undang Kanun Al-Asyi, yang bersumberkan pada ajaran Islam atau suatu kerajaan yang berciri khas Islam. Demikian juga pada Kerajaan Aceh, walaupun berbentuk kerajaan kebijakan tidaklah berbentuk diktator. Buktinya pada Kerajaan Aceh selain dipimpin oleh seorang Raja, juga ada beberapa Sulthanah seperti Ratu Safiatuddin.

Sistem sosial dalam masyarakat atau dalam organisasi masyarakat, baik rumah tangga desa maupun kecamatan, setelah mempunyai peraturan undang-undang mempunyai pemimpin dan mempunyai rambu-rambu atau batas-batasnya maka, untuk menjalankannya dibutuhkan media atau alat guna sampainya tujuan dari or- ganisasi tersebut. Dalam pepatah Aceh disimbolkan dengan Pukat Meukadja. Pukat adalah (alat penangkap ikan tradisional) sejenis nyaring yang digunakan untuk menangkap ikan di laut. Dengan kata lain media atau alat untuk mencapai tujuan tersebut semestinya dirancang sedemikian rupa sehingga pesan yang akan disampaikan dapat langsung diterima masyarakat. Dalam hal ini pukat meukaja dapat juga disimbolkan dengan manajemen dalam suatu organisasi. Artinya, dalam suatu organisasi, katakanlah di desa, tentunya para pemimpin desa harus mempunyai sistem pelaksanaan dan pengontrolan guna memimpin masyarakat tersebut. Manajemen dan pengorganisasian merupakan suatu syarat yang mutlak penting sehingga sistem masyarakat berjalan sebagaimana mestinya.

Sebagaimana diketahui di dalam masyarakat terdapat seperangkat lembaga sosial guna mengatur sistem masyarakat yang telah dicanangkan oleh para pemimpin dan para ulama tempo dulu. Keberadaan lembaga tersebut dapat membatu kelancaran roda pemerintahan, baik di tingkat desa, pemukiman, nanggroe, Sagoe sampai tingkat negara atau kerajaan. Menurut Hasjmy dalam Kanun AI-Asyi lembaga sosial atau lembaga kerajaan diistilahkan dengan Balai baik lembaga eksekutif, yudikatif mauplln legislatif, baik pada tingkat wazirah. (Departemen) maupun pada tingkat idarah Qawatan). Di antara lembaga-lembaga yang termaktub dalam Kanuri Meukuta alam AlAsyi yaitu sebagai berikut:

1. Balai Imam Malikul Islam, yaitu kantor Sultan (semacam Bina Graha dalam Republik Indonesia).

2. Balai Kadli Malikul Adil, kantor Kadli Mu'adham (kira-kira Mahkamah Agung dalam Republik Indonesia).

3. Balai Rama Setia, kantor Wazir Rama Setia Katibul Muluk (kira-kira Sekretariat Negara dalam Republik Indonesia). 
4. Balai Furdhah, yang dipimpin oleh Sri Maharaja Wazir Tijarah (kira-kira Departemen Perdagangan dalam Republik Indonesia).

5. Balai Lakseumana, yang dipimpin Paduka Diraja Wazir AI Harb (kira-kira Departemen Pertahanan dalam Republik Indonesia).

6. Balai Majlis Mahkamah, yang dipimpin Sri Raja Panglima Wazir Mizan (kirakira Departemen Kehakiman dalam Republik Indonesia).

7. Balai Baitul Mal, yang dipimpin Orangkaya Bendahara Raja Wazir Derham (kira-kira Departemen Keuangan dalam Republik Indonesia).

8. Balai Mangkubumi, yang dipimpin Sri Maharaja Wazir Mangkubumi, yang mengurus Hulubalang-Hulubalang (kira-kira Departemen Dalam Negeri dalam Republik Indonesia).

9. Balai Badhul Muluk, yang dipimpin Paduka Diraja Wazir Badlul Mliluk, yang mengurus perutusan dari luar negeri dan perutusan Aceh ke luar negeri (kira-kira Departemen Luar Negeri dalam Republik Indonesia).

10. Balai Kun Diraja, yang dipimpin Sri Maharaja Kun Diraja, yang bertugas mengurus urusan-urusan Dalam (Kraton) dan merangkap menjadi Syahbandar Besar Ibukota Negara Banda Aceh Darussalam.

11. Balai Gurah, yang dipimpin oleh Sri Maharaja Wazir Gurah, yang bertugas mengurusi urusan-urusan hutan, tanaman dan hasil-hasil laut (kira-kira Departemen Pertanian/Kehutanan dalam Repllblik Indonesia).

12. Maharaja Garut, yang dipimpin oleh Keujruen Maharaja Plirba Wazir Paduka raja, yang mengurusi urusan Istana Darud Dunya.
Lembaga sosial di Aceh sebenarnya telah lengkap, sebagaimana negara dan kerajaan-kerajaan lain di dunia. Akan tetapi istilah lembaga sosial dan institusi sosial tersebut disesuaikan dengan ideologi dan agama masyarakat. Kenyataan tersebut dapat dilihat dari istilah-istilah yang dipakai pada lembaga yang ada di Aceh. Istilah lembagalembaga tersebut selain diberi nama dengan sebutan Aceh juga diberi nama dengan istilah bahasa Arab, karena pengaruh Timur Tengah atau dunia Arab sangat dominan dalam masyarakat Aceh. Realitas tersebut sebelum Indonesia merdeka atau pada mas a kejayaan Aceh, Kerajaan Aceh mempunyai hubungan yang sangat erat dengan dunia Islam. Di samping itu hampir semua masyarakat Aceh yang pergi ke luar negeri untuk menuntut ilmu ke luar negeri ke Persia, Mesir, Irak, dan India.

\section{Relevansi dalam Memberi Warna Kebangsaan}

Struktur masyarakat Aceh seperti telah dipaparkan di atas, saat ini sebagian masih dipertahankan dalam kehidupan masyarakat Aceh. Istilah-istilah tersebut dipertahankan pada satu spketrum, tetapi juga disesuaikan dengan keadaan ketika pemerintah menggulirkan programnya dengan istilah-istilah seperti Rukun Tetangga (RT), Rukun Warga (RW), dll. Terminologi seperti di Aceh ini bahkan dapat kita temukan pada komunitas masyarakat lain, seperti di Minangkabau dengan terminologi nagari-nya dll.

Apa yang menjadi kekhasan pada komunitas Aceh dengan struktur masyarakatnya menunjukkan bahwa Indonesia kaya akan entitas budaya. Pada masyarakat majemuk seperti Indonesia, persoalan etnisitas dan kesukuan merupakan suatu persoalan yang membutuhkan perhatian semua pihak. Artinya, identitas etnik dan identitas nasional seringkali membingungkan. Hal ini ka- 
rena identitas etnik lebih menonjol daripada identitas nasional. Untuk melihat masyarakat Indonesia pada masa yang akan datang, identitas nasional merupakan kemutlakan yang diperlukan guna menghadapi dunia global sehingga akan lahir masyarakat yang kosmopolitan. Artinya, masyarakat yang kosmopolitan akan menjunjung tinggi perbedaan budaya dan keanekaragaman. Masyarakat majemuk akan membentuk pemahaman akan kebudayaan secara universal.

Pierre L. Van den Berghe dalam Wibowo (1998: 25) menyebutkan bahwa di dalam masyarakat majemuk terdapat segmentasi sekaligus subbudaya tersendiri dari bagian masyarakat. Untuk melihat segmentasi dalam masyarakat yang majemuk tidak perlu kita berprasangka terhadap identitas nasional. Identitas nasional merupakan konsensus dari masyarakat secara keseluruhan. Jika para pengambil kebijakan memberlakukan kesejahteraan dan keadilan, segmentasi itu merupakan kendala dalam membentuk identitas nasional.

Apa yang ada di dalam struktur masyarakat Aceh tersebut berfungsi sebagai pengendali sosial sekaligus pengisi bagi warna kebangsaan Indonesia. Pengendalian sosial merupakan usaha untuk mencegah terjadinya gangguan pada keserasian dan ketidakpastian. Di samping itu, pengendalian sosial juga dapat mengembalikan keharmonisan dan keserasian melalui sosialisasi. Pengendalian sosial yang bersifat preventif dalam masyarakat yang multikultur dapat diatur sedemikian rupa dengan menampung semua kepentingan yang ada di dalam masyarakat. Dalam masyarakat yang multikultural diharapkan pemerintah tidak menyinggung wilayah yang sangat sensitif, seperti masalah suku, agama, dan ras.
Sehubungan dengan perkembangan sistem kebudayaan dan peradaban masyarakat Aceh, pengendalian sosial sedikit banyak dipengaruhi oleh norma-norma, adat, hukum dan agama Islam. Pengendalian sosial dalam masyarakat Aceh sejak dulu sudah berlaku, misalnya di dalam lembaga keluarga. Keluarga merupakan organisasi terkecil dari masyarakat.

\section{Penutup}

Secara garis besar, terminologi struktur masyarakat Aceh memiliki kaitan dengan semangat keacehan yang dimiliki komunitas ini. Hal ini dapat diketahui pada kekuatan magis terminologi tersebut terhadap semangat juang masyarakat di Aceh. Penggunaan terminologi-terminologi tersebut di satu sisi pernah dimanfaatkan pada saat Aceh bergejolak untuk membangkitkan rasa "perlawanan". Manakala sekarang Aceh telah damai, alangkah indahnya apabila terminologi tersebut dikelola untuk kembali membangkitkan semangat itu. Semangat yang tentu saja memiliki relevansi dengan persatuan dan kesatuan bangsa. Terminologi itu jangan lagi disalahgunakan untuk pemakaian yang bersifat sesaat, apalagi untuk tujuantujuan yang kurang baik.

\section{Daftar Pustaka}

Alfian (editor). 1997. "Segi-Segi Sosial Budaya Masyarakat Aceh". Hasil penelitian metode grounded research. Jakarta: Lembaga Penelitian, Pendidikan, dan Penerangan Ekonomi dan Sosial.

Hanafiah, M. Adnan, Ibrahim Makam. 1984. Struktur Bahasa Aceh. Jakarta: Pusat Pembinaan dan Pengembangan Bahasa, Depdikbud.

Harsojo. 1999. Pengantar Antropologi. Jakarta: Putra Abardin. 
Ismail, Muhammad Gade. 1994. Tantangan dan Rongrongan terhadap Keutuhan dan Kesatuan Bangsa: Kasus Darul Islam di Aceh. Jakarta: Depdikbud.

Sarjono, Agus R. (editor). 1999. Pembebasan Budaya-budaya Kita. Jakarta: Gramedia Pustaka Utama.

Sulaiman, Nasruddin dkk. 1992. Aceh, Manusia Adat dan Budaya. Banda Aceh: Pusat Dokumentasi dan Informasi Aceh.
Sugono, Dendy dkk. (editor). 2005. Kamus Besar Bahasa Indonesia edisi 3. Jakarta: Balai Pustaka Usman, Rani. 2003. Sejarah Peradaban Aceh. Jakarta: Yayasan Obor

Wibowo, Agus Budi. 1998. "Struktur Masyarakat Aceh". Laporan penelitian (tidak diterbit). Banda Aceh: Balai Kajian Sejarah dan Nilai Tradisional Banda Aceh 